\title{
The Evolution of Democratic Socialism Ideas in China and Its Realistic Reflection
}

\author{
XuDanDan ${ }^{1, a}$, WangBian ${ }^{2, b^{*}}$

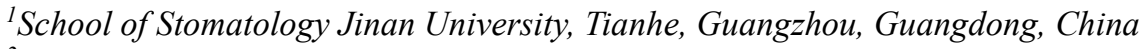 \\ ${ }^{2}$ School of Marxism Jinan University, Tianhe, Guangzhou, Guangdong, China \\ a774576687@qq.com \\ b1151667056@qq.com
}

\begin{abstract}
More than 40 years after the reform and opening up, The introduction of the thought on socialism with Chinese characteristics for Xi Jinping's new era shows that China's socialist construction has reached a new level, and it is also to build a new discourse environment for the study of democratic socialism under a new historical conditions. In today's era, absorbing and drawing lessons from the essence of democratic socialism, which can provide new theoretical value and practical experience for building socialism with Chinese characteristics, and also provides reference for better demonstrating the superiority of the socialist system.
\end{abstract}

Keywords: Democratic Socialism, Socialism with Chinese Characteristics, Reflect on the evolution

\section{我国民主社会主义思潮演变及其现实反思 \\ 许丹丹 ${ }^{1, a}$, 王变 ${ }^{2,} \mathrm{~b} *$}

\author{
${ }^{1}$ 暨南大学口腔医学院, 天河, 广州, 广东, 中国 \\ 2 暨南大学马克思主义学院, 天河, 广州, 广东, 中国 \\ a774576687@qq.com \\ b1151667056@qq.com
}

\section{摘要}

改革开放四十多年，习近平新时代中国特色社会主义思想的提出彰显我国社会主义建设迈上了一个新台阶，更 是为新的历史条件下研究民主社会主义构建新的话语环境。在当今时代, 吸收和借鉴民主社会主义的精髓, 为 建设中国特色社会主义提供新的理论价值和实践经验，也为更好彰显社会主义制度优越性提供参考。

关键词：民主社会主义，中国特色社会主义，反思演变

\section{1. 民主社会主义的发展流变}

民主社会主义，也称社会民主主义，它已有 170 多年的发展历史, 是同工人运动相伴出现的。民主社 会主义是英国工党和其他发达资本主义国家政党的 右翼社会党理论家所宣扬的一种现代改良主义思潮, 主张以非暴力的循序渐进的改良方式一一即民主的 方式缓解社会矛盾以实现社会主义的目的。

\section{1. 国外关于 “民主社会主义” 的起源及发展}

“社会主义”一词是从古希腊关于 “人人平等” 的传说而来, 16 世纪托马斯 - 莫尔发表《乌托邦》 一书，寄予了他对未来社会的美好幻想，19 世纪初 “空想社会主义”思想在西欧盛行，其中以圣西门、 欧文、傅立叶为代表人物。空想社会主义后经由马克 思辩证发展形成了科学社会主义。马克思曾在《哲学 的贫困》中指出: “正如经济学家是资产阶级的学术 
代表一样，社会主义者和共产主义者是无产者阶级的 理论家。”[1]

国外有学者提出 “社会民主主义” 这一概念最早 可以追溯到法国二月革命时期, 由法国人赖德律・洛 兰和路易勃朗提出并建立了世界上第一个社会民主 党。“民主社会主义”这个名词第一次正式被提出, 是由德国社会民主党领袖威廉・李卜克内西在一次公 开演讲中一一《论社会民主党的政治立场，特别是对 国会的政治立场》。无论是“民主社会主义”还是“社 会民主主义”，马克思恩格斯都有条件的接受了这个 名词。在革命活动初期, 他们也曾自称社会民主主义 者或者是社会民主党人, 在内容上他们则是用科学社 会主义的观点来解释社会民主主义的内涵。之后各个 国家的社会民主党以此为纲领, 创建了以工人阶级为 首的国际联合组织一一第二国际。。第二国际为推进 国际共产主义运动, 反对军国主义, 加强工人阶级联 合和团结方面, 特别是在对外宣传播马克思主义观 点、内容和方法等方面起到了极其重要的作用。不可 否认的是, 民主社会主义与马克思恩格斯所提倡的科 学社会主义在当时实际上是同一个概念。

19 世纪末 20 世纪初, 马克思恩格斯两人在晚年 时期提出, 资本主义生产方式当中存在的自我扬弃的 动力可以使之和平转变为社会主义生产方式, 不需要 用暴力来消灭私有经济。恩格斯临终前撰写的《〈法 兰西阶级斗争 >导言》, 指出 “利用选举权夺取我们 所能夺得的一切阵地”, 当然恩格斯并未全盘否定不 合法手段。1917 年, 列宁领导的俄国十月革命取得 胜利, 为了与民主社会主义政党划清界限, 俄国社会 民主工党改名为共产党, 并建立共产国际。许多国家 社会民主党中的激进力量纷纷脱离原来的社会党, 组 建共产党。1923 年各国社会民主党组建社会主义工 人国际, 并于 1951 年改称社会党国际。

\section{2. 我国关于 “民主社会主义” 的研究及演变}

我国对于民主社会主义思潮研究的开端, 始于新 中国建立后, 具有浓厚的意识形态批判色彩。20 世 纪 60 年代, 由于中苏关系急剧恶化, 此时在国内, 民主社会主义被定性为资产阶级政党的一种变形。我 国批判民主社会主义的文章铺天盖地, 客观来看一定 程度上曲解了民主社会主义的内容和主张, 某种程度 上是意识形态斗争的结果。

改革开放后, 国内学者陆续出版了一些客观介绍 民主社会主义的文献, 为研究其形成流变提供了大量 信息。1989 年前后东欧剧变, 继而苏联解体。国内 有学者认为, 苏联国家的解体很大程度上来说是由于 自身内部体制僵化、社会矛盾爆发所导致的直接结 果，但是民主社会主义思想在苏联国家内部的 “潜移 默化”, 实际上也是隐匿性地充当了资产阶级思想腐 蚀、消解社会主义的 “利器” 。国际社会與论方面, 苏联解体造成国际社会对整个社会主义的摒弃, 與论 的普遍转向使得民主社会主义在苏东剧变后最初几 年陷入低迷。1992 年 9 月社会党国际十九大中提出
将“社会民主主义”作为社会党思想体系的正式表述， “不应再追求对资本主义的超越，不应再把社会主义 视为制度、目标，而应把社会主义视为通过对现存社 会的不断调整以实现公正、平等、互助的价值目标。” 1992 年邓小平南方谈话, 这一时期国内思想解放兴 起, 各国社会民主党与我国的关系也有了明显的改善 与进步。“1997 年, 社会党国际主席莫鲁瓦访问中 国, 标志着中共与社会党关系正常化。” ${ }^{[2]}$ 英国布莱 尔率领新工党上台执政, 提出实施 “第三条道路”, 做出这样的 “道路” 抉择是想要开辟出介于民主社会 主义和新自由主义的新形态的资本主义道路。不过有 学者评论认为民主社会主义只是扮演了“资本主义病 床边的医生” 这样的角色。

“第三条道路” 理论试图纠正以往民主社会主义 片面注重社会公正, 漠视经济效率的弊端, 尽管它在 不同国家有着不同的表现形式和具体政策, 但基本观 点都是围绕主张私有化、市场化, 减少国家干预, 减 少社会福利的观点来提出, 最终目的是建立 “积极的” 福利国家。总体来说, “第三条道路” 是在坚持民主 社会主义基本价值的前提下，包容和汲取了新自由主 义的一些主张, 目的是使民主社会主义摆脱新自由主 义攻势下而陷入的困境, 为社会党寻求新的发展空 间。同时, “第三条道路” 的提出也表明社会党已经 在一定程度上向右转。

\section{2. “民主社会主义” 的价值诉求}

通过梳理民主社会主义在国际国内的发展流变, 我 们发现时代背景赋予民主社会主义特定的历史内涵, 但 是其所追求核心主张、价值理念并未有大变化。民主社 会主义主张思想多元化, 它承认马克思主义是理论来 源之一, 同时它并不排斥自由主义思想, 认为社会主 义不能将某种固定的哲学或是社会思想作为理论基 础, 而应主动吸收符合其理念价值的思想。“民主社 会主义” 追求自由、平等公正、合作互助，但民主社会 主义者又把社会主义看成是一种道德需要, 否认其历史 必然性。因此民主社会主义作为一种改良主义运动不是 社会发展的必然要求。

\section{1. “民主社会主义” 的经济目标}

在经济建设上，民主社会主义注重繁荣与平等， 关注人们生活，提倡经济民主，它试图以对经济的民 主监督取代消灭私有制。它不赞成没收生产资料全部 归公的做法, 而面向于社会当中存在的生产资料私有 所产生的问题该如何解决, 也就是说私有制如何服务 于改善人们生活问题的解决。民主社会主义主张 “混 合所有制经济” , 通过推行 “工人参与制” , 即通过 让工人或工人代表参与企业经营活动、高层决策等方 面, 具有谈判协商权, 以此克服分配不公。民主社会 主义认为所有制结构都需要以提倡市场调节作用为 前提, 公有制或国有企业在宏观调控, 促进社会公益, 改善民生等方面缓解社会矛盾，而私有制也会在增加 社会财富、努力 “做大蛋糕” ，企业创新等方面也会 
有独特作用。有学者认为, “民主社会主义者企图依 靠经济的民主监督来解决劳资矛盾, 将资本主义改造 成社会主义, 这只能是一种良好的愿望, 是不可能实 现的。”

\section{2. “民主社会主义” 的政治主张}

在政治建设上，民主社会主义主张实行宪政民 主, 否认阶级斗争的存在, 主张尊重多数人的决定, 坚持多党制或多元政体和议会民主，建立一个政治民 主的社会。民主社会主义主张实行分权制衡，支持新 闻自由和司法独立，互相监督，保障和维护民主平等 的人权。以上提出的种种举措在一定程度和范围内冲 破当时的社会氛围，人民的民主权利有了明显 “质” 的飞跃和扩大，人民政治地位在短时间内提高，客观 上迫使资产阶级政党和社会团体在有关于 “人民利 益” 的实践上做出调整和让步, 造成当时的发达资本 主义国家似乎是形成了较为民主的 “假象” 。对于社 会团体的举措, 民主社会主义者则大力支持其活动, 在一定时间段内, 社团活动的良好发展也为保护弱势 群体起到正面作用。“在党建方面, 主张从纲领党进 一步转变为选举党, 淡化意识形态色彩, 以现实需要 和选举需要制订政策, 以争取更多的选民。” ${ }^{[3]}$

\section{3. “民主社会主义” 的社会政策}

在社会政策上，民主社会主义大力建设福利国 家, 利用市场力量服务于公共利益, 完善社会保障制 度。社会党人认为社会主义就是要有完善全面的社会 保障制度, 从摇篮到坟墓, “包括儿童享受福利照顾 的权利, 青少年受教育的权利, 成年人的工作权利、 休息权利、住房权利以及工伤、失业、医疗保障权利, 老年人的养老保障等” ${ }^{[4]}$ 实现从 “消极” 福利国家转 变为 “积极” 福利国家。但希腊爆发债务危机所导致 的连锁反应, 也使得世界各国对现有福利制度进行反 思。高福利的社会制度在一定程度上使贫富差距缩 小, 阶级矛盾缓和, 但同时也发现资本主义社会就在 这样 “紧张” 或 “松弛” 的两度天秤上摇摆, 无法从 根本上解决其结构性问题。民主社会主义仅仅是把这 种社会政策看作是实现社会主义的一个手段, 这种社 会保障制度说到底只能是起 “缓冲器”, 根本上来看 资本主义社会的种种瘨疾是很难解决的。这也不难看 出, 社会保障制度与资本主义的矛盾, 不过是资本主 义社会化大生产与生产资料私人占有制这一基本矛 盾的一种特殊外化表现形式而已。

\section{3. 民主社会主义发展带来的思考}

民主社会主义作为一种社会改良思潮和社会政 治力量, 发展至今有着强劲的生命力。在全球化与改 革开放四十余年的时代背景下, 尤其是十九大以来, 中国历史发展进入新时代, 习近平新时代中国特色社 会主义思想的提出一一为挖掘民主社会主义的理论 意义和实践价值提供新的语境, 也为开展深入对话交
流, 为中国特色社会主义建设研究提供有利资源。

\section{1. “民主社会主义”对中国政治制度的影响}

四项基本原则是我国立国之本, 是党和国家生存 发展的政治基石。中国在长期革命建设和发展过程中 形成了自身特有的政治体系。中国共产党领导的多党 合作和政治协商制度具有坚实的领导地位, 我国政党 制度是维护国家安定团结的核心力量, 这项政党制度 有助于维护国家、民族和人民的安定团结，有利于维 护广大人民群众的核心利益, 它不同于其他国家的一 党制或者两党制, 它是把现代国家中政党制度的一般 取向和中国国家和民族的特殊取向有机地结合起来, 有效避免了多党制造成的权力碾压与混乱。民主社会 主义普遍意义上认为多党制可以分权制衡, 起到权力 监督的作用。但我党在制度设计上, 近年来通过监察 制度、司法制度的不断完善, 使得权力装进制度的“笼 子”。近几年, 党和国家推进政治改革下大力气铲除 腐败, 从根源上解决腐败内生。如果盲目选择所谓多 党制只会导致民族分裂, 终结社会主义现代化建设, 滑向戈尔巴乔夫所谓 “人道的民主的社会主义” 的深 渊。

\section{2. “民主社会主义”对中国经济制度的影响}

改革开放之后，中国发展社会主义市场经济，经 过多年的理论讨论与实践摸索，逐步建立了中国特色 社会主义的基本经济制度一一坚持和完善社会主义 公有制为主体、多种所有制经济共同发展的中国特色 社会主义基本经济制度。这种经济制度符合我国生产 力发展水平, 符合经济社会所面向的主要矛盾。生产 力发展的不平衡需要释放社会创造财富的活力, 调动 各方面积极性，同时在分配方面也需要国家进行宏观 调控, 避免两极分化。在协调眼前利益与长远利益、 解决民生问题与人的全面发展等关系上仍需要强大 的协调权衡能力。民主社会主义以私有制为基础, 主 张混合所有制经济。从形式上看, 它们两者都主张国 家发挥调控作用，尽量释放市场活力。但是从深层次 看, 我国仍处于社会主义发展初级阶段, 经济发展空 间大，上升势头足，而民主社会主义所在的国家已是 发达资本主义国家，它的宏观调控更多的是在缓和社 会矛盾, 解决原先社会问题。全球都处于社会转型阶 段，在这样的背景下寻求制度优势找到发展的突破口 是摆在世界面前的难题。

\section{3. “民主社会主义”对中国指导思想的影响}

在指导思想方面, 我国坚持马克思主义一元指 导, ${ }^{i}$ 民主社会主义正如前文所提到坚持思想多元， 《法兰克福声明》、《哥德斯堡纲领》等众多民主社 会主义代表作都展现了其指导思想的多元化, 本质上 来讲是一种社会的改良思潮。有学者认为其是非马克 思主义的社会主义流派。事实上民主社会主义并没有 一个界限清楚的含义和思想理论体系, 它在继承第二 
国际某些领导人思想传统的基础上, 根据社会发展新 情况以及其他社会思潮作了新的补充和发展, 特别是 在国际问题、发展模式上。中国特色社会主义是建立 在工人阶级领导、工农联盟为基础之上的理论体系, 而民主社会主义的开端虽然以无产阶级为阶级基础, 但发展至今已经逐渐寻求多种力量的支持, 特别是中 产阶级。在变革路径上, 结合我国国情, 自 1949 年 以来我国建设重心由 “阶级斗争为纲” 逐渐摸索出一 条温和的社会主义改革路径, 其发展有一定的转变过 程，仍坚定社会主义取代资本主义的历史规律。而民 主社会主义的发展自其产生之初就强调温和渐进, 也 正因如此对于社会主义的建立他们只是认为需要在 人的道德观念上的完善就可以达到。

\section{4. 结论}

当今世界已经成为 “地球村”, 各国之间紧密联 系, 互相影响。从国内社会发展来看, 自 1978 年改 革开放以来，历经四十多年，我国吸收民主社会主义 在贫困、社会保障和环境保护等方面的经验, 观察其 发展模式当中存在的问题并自省。从世界政治思想来 看, 中国特色社会主义与民主社会主义进行持久对话 和交流的理论要求; 寻求国家的治理和强大, 是我们 从民主社会主义要学习和借鉴积极因素的实践价值。

\section{REFERENCES}

[1] Marx, Engels. Collected Works of Marx and Engels $[\mathrm{M}]$. The third edition. Central Compilation and Translation Bureau, 2012.

[2] Ma Licheng. Eight Social Thoughts in Contemporary China[M].Beijing: Social Sciences AcademicPress (CHINA), 2012:93.

[3] Wang Weiping. The Overview of the Research on Democratic Socialism at Home and Abroad Since 1990s [J]. Science Economy Society, 2010, 28(04) : 101-105+110.

[4] Ma Licheng. Eight Social Thoughts in Contemporary China[M]. Beijing: Social Sciences Academic Press (CHINA), 2012 :93.

[5] Nicolas Gachon. Bernie Sanders's Democratic Socialism[M].:2021-03-22.

[6] Goldman Paul,Adler Paul,Case Ann,Deaton Angus,Hochschild Arlie,LeGuin Ursula,Piketty Thomas,Goldhamer Arthur. Book Review: Paul Adler <italic $>$ The 99 Percent Economy: How Democratic Socialism Can Overcome the Crises of Capitalism $<$ italic $>[\mathrm{J}]$.

Organization Studies, 2021,42(1).

[7] Carey Seamus. How to understand democratic socialism[J]. Guardian (Sydney),2020(1908).
[8] Gary Dorrien. Revising Democratic Socialism[J]. CrossCurrents,2020,70(1).

[9] Peng Lifang. Carsun Chang on Democratic Socialism: Liberalism, Social Democracy, and German Idealism[J]. American Journal of Chinese Studies,2019,26(2). 